\title{
Evaluation of New Molecules for Management of Stem borers on Sugarcane
}

\author{
A. Padmasri ${ }^{1}$, G.E.Ch. Vidyasagar ${ }^{2}$ and V. Bharathi ${ }^{3}$ \\ ${ }^{1,2,3}$ Seed Research and technology centre, Rajendranagar, Hyderabad, College of Agriculture, Rajedranagar, \\ Hyderabad, Seed Research and technology centre, Rajendranagar.
}

\begin{abstract}
An experiment was conducted at Regional Sugarcane and Rice Research Station, Rudrur during 2011 and 2012, to assess the chemical control of sugarcane stem borers (Chilo infuscatellus and Chilo sachariphagus indicus). Seven insecticides namely, Rynaxypyr $0.4 \%$, Spinosad 45 SC, Acephate 75 SP, Chloropyriphos 20 EC, Chloranthriniliprole 18.5 SC, Indoxicarb 14.5 SC, Flubendamide 480 SC and compared with untreated (Check plot) using randomized block design with three replications. Significant differences were noticed among the treatments. The lowest per cent mean cumulative incidence of early shoot borer (11.61) at 45, 60, 90 and 120 days after planting and lowest per cent intensity (1.48) and incidence (1.21) of inter nodal shoot borer was recorded in Chloranthriniliprole $18.5 \mathrm{SC} @ 0.36 \mathrm{ml} / \mathrm{l}$ of water. Further, the same treatment recorded significantly superior cane yield of 85.05 t/ha, while the untreated control recorded 79.01 t/ha. Among

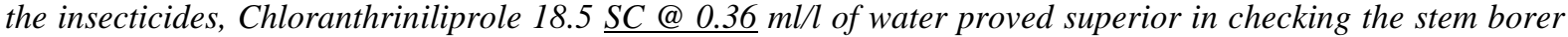
infestation over rest of the insecticides tested.
\end{abstract}

Key words: Early shoot borer, Inter node borer, Management.

\section{Introduction}

The importance of sugarcane (Saccharum officinarum 1) in the agrarian economics of India needs no emphasis because of its high value as a cash crop, a major source of white sugar and gur. Sugarcane crop is currently facing severe crises in the country and both farming community and the industry are striving for its sustainable existence and growth. The major challenges faced by the crop are lower than average per area production, low sugar recovery and higher cost of production. Regardless of pronounced development in sugarcane research and expansion in sugar industry, our national average cane yield is 70.3 tons per hectare, where as the potential between 100-120t/ha. There are several reasons for this low yield but different types of borer and the most serious pest of sugarcane, of which the stem borer Chilo infuscatellus is the most notorious and destructive one. The early shoot borer damages cane crop mainly at formative phase. The young larvae bore down the spindles as also upwards destroying the apical meristem. Consequently the cut of spindle dries up and develops into a conspicuous "dead heart" that can be pulled out easily and emit a rancid odour. The killing of mother shoots and tillers are resulted in to gap. The damage Chilo infuscatellus ranges from 30-75 per cent in early stages of the crop (may- June) in subtropical India.(KrishnamurthyRao, 1954). The neglected crop therefore, may suffer heavy losses in tonnage due to this borer species. Infestation and subsequent damage by inter node borer Chilo sacchariphagus indicus is matter of concern. Among the pest, Gupta (1993) reported more than 45 per cent of yield losses in sugarcane are due to infestation by borer pests alone.

Keeping in view the economics, importance of the pest and the crop, field studies were carried out to determine the chemical control measures for sugarcane stem borer at Regional Sugarcane Research Station, Rudrur.

\section{Material And Methods:}

In order to assess the chemical control of sugarcane stem borer on sugarcane an experiment was conducted at Regional Sugarcane Research Station, Rudrur, during the crop season 2012-2013. Homogenous sets of standard commercial sugarcane variety was planted during last week of February 2012 in rows keeping $90 \mathrm{~cm}$ distance between row to row and $15 \mathrm{~cm}$ distance between set to set. A three replicated randomized block design was laid out with a net plot size $8 \times 6 \mathrm{~m}^{2}$. Seven insecticides were tried and compared with an untreated plot control viz., Rynaxypyr $0.4 \% \mathrm{G}$, Spinosad 45 SC, Acephate 75 SP,Chloropyriphos 20EC, Chloranthriniliprole 18.5 SC, Indoxicarb 14.5 SC, Flubendamide 480 SC. First application of these insecticides was done at 30 days after planting. Second application was made in the month of June against Internode shoot borer.

Observations on the incidence of ESB, was recorded on 45, 60, 90 and 120 DAP and per cent shoot borer incidence was worked out.

The incidence of sugarcane internode borer was observed and evaluated during the $5^{\text {th }}, 7^{\text {th }}, 9^{\text {th }}$ 
month of the crop growth and at the harvest( $12^{\text {th }}$ month). The number of stalks which had entry holes of the neonate larva and if fecal matter on the leaf sheath was recorded to calculate the per cent incidence. The intensity of Internode shoot borer was calculated by splitting all the canes stalks and measuring the number of nodes affected by the larva per stalk of the cane. The per cent infestation was calculated by formula given below.

Pest incidence and pest intensity were calculated using following formulae:

1. Per cent inter node shoot borer incidence $=\underline{\text { affected canes }} \times 100$

total cane

2. Per cent inter node shoot borer intensity $=\underline{\text { affected nodes }} \times 100$

total nodes

3. Per cent inter node shoot borer infestation $=$ per cent incidence $\mathrm{x}$ per cent intensity

100

The yield parameters like cane yield, commercial cane sugar per cent were recorded and cane population and sugar yield were worked out. The experiments were subjected to statistical analysis following the method of Panse and Sukhatme (1985).

Benefit cost analysis of the treatments: In order to find out the cost/benefit analysis of the treatment versus control, total yield was converted into yield per hectare. The yield /ha were then multiplied with unit price of the cane to get gross income of the treatment. The incremental returns were obtained by subtracting the gross income from the check plot income. The cost of treatment was calculated on hectare basis. The net benefit was obtained by subtracting the total cost of the treatment from the gross income of the treatments. Cost benefit ratio were calculated through gross income divided by total cost. Greater the C: B ratio indicates the efficiency of the treatment.

\section{Results And Discussions:}

The results on the per cent cumulative incidence of early shoot borer at 45,60,90 and 120 days after planting are presented in Table1. Chloranthriniliprole $18.5 \mathrm{SC} @ 0.36 \mathrm{ml} / 1$ of water recorded the lowest per cent (11.07) incidence. However, it is at par with Flubendamide 480 SC @0.2 ml/1 (12.33), Spinosad 45 SC @0.3 $\mathrm{ml} / \mathrm{l}$ (12.34), Indoxycarb $14.5 \mathrm{SC} 13.74 @ 1 \mathrm{ml} / 1$ and these are significantly superior to Acephate $75 \mathrm{SP}$ (14.05) and Chlorpyrifos 20 EC (15.73).The plot receiving Chloranthriniliprole $18.5 \mathrm{SC} @ 0.36 \mathrm{ml} / \mathrm{l}$ of water recorded minimum population build up of internode borer there by providing the most effective of all the treatment (1.21 per cent) followed by Flubendamide 480 SC @ 0.2 ml/1(5.42) and Spinosad 45 SC @ $0.3 \mathrm{ml} /$ liter(6.28 per cent). The lowest per cent intensity of internode shoot borer (1.48) was recorded in Chloranthriniliprole 18.5 SC however, it is at par with Spinosad 45 SC (2.26) and Flubendamide 480 SC (2.42). Chloranthriniliprole 18.5 SC $@ 0.36 \mathrm{ml} / 1$ of water recorded the highest per cent sucrose (16.88) and highest per cent purity (85.79 per cent), however there is no significant difference among the treatments with respect to number of millable canes.

\section{Cost benefit analysis of insecticidal treatment :}

The results in table 3 revealed that the maximum net returns was recorded with Spinosad 45SC (4.31) followed by Flubendamide $480 \mathrm{SC}$ (3.69) and Indoxicarb $14.5 \mathrm{SC}$ (3.14) as compared to check plot with cost benefit ratio of 1.Chloranthriniliprole 18.5 SC has the highest cost than all other test insecticides but it gave the maximum reduction in early shoot borer and internode borer with $\mathrm{C}: \mathrm{B}$ ratio (1:3.0). The present findings are in agreement with the observations of Singh et.,al.(2009) reported Rynaxypyr 20 Sc @ 100 gai/ha was found to be best with minimum 0.12 per cent infestation by early shoot borer and gave maximum yield of $77.13 \mathrm{t} / \mathrm{ha}$. Jaipal et., al (2010) recorded similar observations and reported that the mean incidence of shoot borer was lowered by 60 per cent due to Rynaxy pyr 20 SC treatment given as root drench and registered significantly increased cane yield over the untreated control as well as the standard recommended insecticides Carbofuran.

Thus insecticides Chloranthriniliprole 18.5 SC could be selectively used in the management of sugarcane borers to get highest yield.

\section{References}

[1]. Gupta, S.C., Yazdani, S.S., Hameed, S.F. and Agarwal, M.L.(1993). Losses in sugarcane by different broods of top borer, Scirpophaga excerptalis Walker in northern Bihar.J. Insect Sci. , 6(1): 125-127.

[2]. Jaipal,S., Chaudary,O.PS., and Prasad, R.2010. Evaluation of rynaxypyr (Coregen) 20 SC for the management of early shoot borer and top shoot borer in sugarcane. Indian journal of sugarcane technology, 25(1\&2):47-50.

[3]. Krishnanurthy Rao, B.H. 1954. Apparent and actual yield of sugar cane and the part played by stem borers. Proc. A.Conv. Sug. Technol. Assoc. India, 23: 25-27

[4]. Pause,V.G., and Sukhatme,P.K, 1985. Statistical methods for Agricultural workers, ICAR,New Delhi.

[5]. Singh, G.,Prasad, C.S., Sirohi,A., Kumar,A. and Ali., N.2009. Field evaluation of Rynaxypyr 20SC against insect pests of sugarcane. Annuals of plant protection sciences, 17(1):75-79 
Table 1 Evaluation of new molecules for the management of key pest on Sugarcane.

\begin{tabular}{|c|l|c|c|c|c|c|c|}
\hline $\begin{array}{c}\text { S. } \\
\text { No }\end{array}$ & \multicolumn{1}{|c|}{ Treatments } & $\begin{array}{c}\text { Per cent } \\
\text { Cumulative } \\
\text { incidence of } \\
\text { Early shoot } \\
\text { borer }\end{array}$ & $\begin{array}{c}\text { Per cent } \\
\text { reduction } \\
\text { over the } \\
\text { control }\end{array}$ & $\begin{array}{c}\text { Per cent } \\
\text { Intensity } \\
\text { of ISB }\end{array}$ & $\begin{array}{c}\text { Per cent } \\
\text { reduction } \\
\text { over the } \\
\text { control }\end{array}$ & $\begin{array}{c}\text { Per cent } \\
\text { Incidence } \\
\text { of ISB }\end{array}$ & $\begin{array}{c}\text { Per cent } \\
\text { reduction } \\
\text { over the } \\
\text { control }\end{array}$ \\
\hline 1 & Rynaxypyr 0.4 \%G & $16.60(19.56)$ & 15.52 & 4.85 & 48.67 & 15.89 & 11.12 \\
\hline 2 & Spinosad 45SC @ & $12.34(7.09)$ & 37.20 & 2.26 & 76.08 & $6.28(3.60)$ & 64.48 \\
\hline 3 & $\begin{array}{l}\text { Acephate 75 SP @ } \\
1.5 \text { g/lt }\end{array}$ & $14.05(8.07)$ & 28.49 & 4.44 & 53.01 & 14.43 & 19.29 \\
\hline 4 & Chlorpyriphos 20 EC & $15.73(9.05)$ & 3.92 & 6.66 & 29.52 & 15.30 & 14.42 \\
\hline 5 & Chloranthriniliprole & $11.07(6.35)$ & 43.66 & 1.48 & 84.33 & $1.21(0.69)$ & 93.23 \\
\hline 6 & Indoxicarb 14.5 SC & $13.74(7.89)$ & 30.07 & 3.12 & 66.98 & $7.85(4.50)$ & 56.09 \\
\hline 7 & Flubendamaid 480 & $12.33(7.08)$ & 37.25 & 2.42 & 74.39 & $5.42(3.11)$ & 69.68 \\
\hline 8 & Untreated control. & $19.65(13.33)$ & & 9.45 & & 17.88 & \\
\hline & F test & Sig & & Sig & & Sig & 2.74 \\
\hline & CD \% & 2.77 & & 1.54 & & & 25.94 \\
\hline
\end{tabular}

Figures in the parenthesis are arcsine transformed values.

Table 2 Effect of the new molecules on yield parameters and cost benefit ratio

\begin{tabular}{|c|l|c|c|c|c|}
\hline $\begin{array}{c}\text { S. } \\
\text { No. }\end{array}$ & \multicolumn{1}{|c|}{ Treatments } & $\begin{array}{c}\text { Per } \\
\text { cent } \\
\text { sucrose }\end{array}$ & $\begin{array}{c}\text { Per } \\
\text { cent } \\
\text { purity }\end{array}$ & NMC / ha & $\begin{array}{c}\text { Cane } \\
\text { yield } \\
\text { t/ha }\end{array}$ \\
\hline 1 & Rynaxypyr 0.4 \%G & 15.03 & 68.42 & $75,739.00$ & 80.25 \\
\hline 2 & Spinosad 45SC @ 0.3 & 16.59 & 77.34 & $79,873.00$ & 83.16 \\
\hline 3 & $\begin{array}{l}\text { Detrashing followed by } \\
\text { cnraninn Ananhata 75 cD }\end{array}$ & 15.95 & 76.85 & $77,528.00$ & 82.02 \\
\hline 4 & Chlorpyriphos 20 EC @ & 15.87 & 75.39 & $77,213.00$ & 80.65 \\
\hline 5 & Chloranthriniliprole 18.5 & 16.88 & 85.79 & $81,496.00$ & 85.05 \\
\hline 6 & Indoxicarb 14.5 SC @ & 16.14 & 77.13 & $79,873.00$ & 84.01 \\
\hline 7 & Flubendamaid 480 SC @ & 16.79 & 82.62 & $79,209.00$ & 83.68 \\
\hline 8 & Untreated control. & 15.74 & 69.39 & $78,152.00$ & 79.01 \\
\hline & F test & Sig & Sig & NS & Sig \\
\hline & CD \% & 0.70 & 1.95 & - & 2.27 \\
\hline & CV \% & 2.48 & 1.45 & - & 1.58 \\
\hline
\end{tabular}

Figures in the parenthesis are arc sine transformed values.

Table-3:Cost/benefit analysis of insecticides.

\begin{tabular}{|l|l|l|l|l|l|}
\hline Treatments & $\begin{array}{l}\text { Estimated } \\
\text { yield t/ha }\end{array}$ & $\begin{array}{l}\text { Increase over } \\
\text { the control in } \\
\text { tonne }\end{array}$ & $\begin{array}{l}\text { Benefit } \\
\text { Rs }\end{array}$ & $\begin{array}{l}\text { Cost/Benefi } \\
\text { Ratio }\end{array}$ \\
\hline Rynaxypyr 0.4 \% G@ 8kg/acre & 80.25 & 1.24 & 3,224 & 2,829 & $1: 1.3$ \\
\hline Spinosad 45SC @ 0.3 ml/lt & 83.16 & 4.15 & 10,790 & 2,500 & $1: 4.31$ \\
\hline $\begin{array}{l}\text { Detrashing followed by spraying } \\
\text { Acephate 75 SP @ 1.5 g/lt }\end{array}$ & 82.02 & 3.01 & 7,826 & 2,651 & $1: 2.95$ \\
\hline Chlorpyriphos 20 EC @ 2.5ml/lt. & 80.65 & 1.64 & 4,264 & 1,640 & $1: 2.60$ \\
\hline $\begin{array}{l}\text { Chloranthriniliprole 18.5 SC @ } \\
\text { 0.36 ml/lt }\end{array}$ & 85.05 & 6.04 & 15,704 & 5,350 & $1: 3.00$ \\
\hline Indoxicarb 14.5 SC @ 1 ml/lt. & 84.01 & 5.00 & 13,000 & 4,140 & $1: 3.14$ \\
\hline Flubendamaid 480 SC @ 0.2 ml/lt & 83.68 & 4.67 & 12,142 & 3,282 & $1: 3.69$ \\
\hline Untreated control. & 79.01 & & & & \\
\hline
\end{tabular}

